\title{
PUBLIC VALUES REGARDING AN URBAN MANGROVE WETLAND IN THE UNITED ARAB EMIRATES
}

\author{
Hamed ASSAF $^{*}$, Sahar IDWAN ${ }^{2}$, Abdul Halim JALLAD ${ }^{3}$, Madiha Z. J. AMMARI ${ }^{4}$, \\ Aktham Al CHAAR ${ }^{5}$, Mahmoud KOUJA ${ }^{6}$ \\ ${ }^{1}$ Department of Civil and Infrastructure Engineering, American University of Ras Al Khaimah, \\ Ras Al Khaimah, U.A.E. \\ ${ }^{2}$ Faculty of Information Technology, The Hashemite University, Zarqa, Jordan \\ ${ }^{3}$ Department of Electrical Engineering, United Arab Emirates University, Al Ain, Abu Dhabi, U.A.E. \\ ${ }^{4}$ Department of Civil, Environmental and Geodetic Engineering, The Ohio State University, USA \\ ${ }^{5}$ Department of Civil Engineering, American University of Sharjah, Sharjah, U.A.E. \\ ${ }^{6}$ Advanced Construction Technology, Dubai, U.A.E.
}

Received 21 August 2020; accepted 26 October 2021

\footnotetext{
Highlights

Environmental values are assessed with respect to mangrove wetlands in the UAE.

$>$ Residency and sustainability awareness highly influence value orientations.

$\checkmark$ Value orientations are less associated with age, mangrove knowledge and education.

Value orientations are largely independent of gender and income.

Public is generally biocentric with respect to the protection of the mangroves.
}

\begin{abstract}
Mangrove wetlands are facing an existential threat from rapid socio-economic development. In this study, public environmental values regarding mangrove wetlands in the Ras Al Khaimah (RAK) city in the United Arab Emirates were assessed, considering gender, age, education, income, length of residency in RAK, knowledge of RAK mangrove and awareness of sustainability. A population sample of 427 respondents were face-to-face interviewed. Results suggest that mangrove value orientations are highly associated with length of residency in RAK and awareness of sustainability at significance levels of 0.003 and 0.005 , respectively. Value orientations are less associated with age, knowledge of RAK mangrove and education at significance levels of $0.023,0.039$ and 0.095 , respectively, being largely independent of gender and income. The majority of the respondents support the preservation of the mangroves even at the expense of economic development. This indicates the need to draft policies and regulations to safeguard the mangroves.
\end{abstract}

Keywords: mangrove, environmental sustainability, environmental management, landscape management, environmental values, survey.

\section{Introduction}

Rapid urbanization of human settlements across the world implies that many urban areas have and will continue to come in contact with ecological systems, with environmental consequences; hence, it is necessary to study the impact of urbanization on natural ecosystems, and how it can be mitigated. In general, the impact of urbanization tends to be negative, as human settlements require clearing land for housing, infrastructure, and agriculture. These human actions have resulted in the destruction of the habitats for many species, and in critical cases could lead to the ultimate loss or near extinction of many species. Examples include the case of orangutans in Indonesia, tigers in India, and many species on the African continent (see Nasution et al., 2018; Joshi et al., 2016). Europe and the Middle East have lost many of their indigenous species over millennia, as humans considered some species as pests and have ended up eradicating them altogether. For example, the grey wolf was considered a harmful pest in Europe over several centuries. Great efforts were made to exterminate

*Corresponding author. E-mail: hamed.assaf@aurak.ac.ae

Copyright @ 2022 The Author(s). Published by Vilnius Gediminas Technical University

This is an Open Access article distributed under the terms of the Creative Commons Attribution License (http://creativecommons.org/licenses/by/4.0/), which permits unrestricted use, distribution, and reproduction in any medium, provided the original author and source are credited. 
the grey wolf population. In France, the grey wolf population was wiped out by 1930 (Moriceau, 2014).

Although few flora and fauna have managed to survive in the harsh environment of the Arabian Gulf (Naser, 2014), they are coming under intense pressure from the recent massive socio-economic development fueled by oil revenues. Of a particular concern are the coastal developments - including the construction of large urban areas on areas reclaimed from the Gulf - that have reshaped the hydrology and water circulation of intertidal zones as well as the habitat of mangroves (Naser, 2014). One of the ecosystems under threat is the mangrove wetland situated in the center of Ras Al Khaimah (RAK) city, the capital of Ras Al Khaimah emirate, which is one of the seven emirates that make up the United Arab Emirates. The mangrove wetland in RAK city represents an urban ecological system, completely enclosed within the city center (Figure 1). The geographic setting is not a coincidence, since the RAK mangrove wetland with its calm water, abundance of fish, fiber, and food for livestock was a great attraction to the earlier settlers of the area. Archeological records show that the area was inhabited for millennia. There are archeological evidences that the mangrove wetlands in the UAE were important fishing ground (Beech \& Hogarth, 2002). Wood from mangrove was used in shipbuilding and construction of houses. Archeological deposits in Ras Al Khaimah that date back to the Sasanian/Islamic period contained significant amounts of shell remains of a crab species that once dominated the mangrove wetlands. This indicates that the mangroves - then more wide spread - provided an important food source for the inhabitants (Beech \& Hogarth, 2002).

Today, the RAK mangrove wetland sits on a vulnerable land lined by commercial and residential areas including popular golf fields (Figure 1). The mangroves are threatened by dredging activities, and are exposed to solid waste dumping and wastewater runoff from nearby buildings. However, urban mangrove ecosystems, such as the RAK mangrove wetland, are recognized for a range of ecosystem services including carbon sequestration (Atchison, 2019), improving air quality (Hsieh et al., 2015), and the reduction of urban heat island impact (Lazzarini et al., 2012). Earlier survey testing by the authors showed that only few residents of RAK city are aware of the significance of the mangroves and their ecosystem services, and the threat they are facing from human activities. Setting effective policies and measures to protect the RAK mangrove wetland requires understanding how the public perceive them, and how supportive they are of conservation efforts. Given the lack of such information, the authors conducted the current study to assess public environmental values regarding mangroves, and how they are associated with economic and demographic factors.

\section{Literature review}

\subsection{Brief overview of mangrove ecosystems}

Mangroves are a diverse group of trees and shrubs that dominate the intermittently inundated intertidal zones. Mangroves distribute from the latitudinal belt from $25^{\circ}$ South to $25^{\circ}$ North, with a high diversity of species in the equatorial regions in Southeast Asia, because of their sensitivity to cold winters (Feller, 2018). Only a few species of mangrove survive further south or north of this latitudinal range, with the southern coasts of the Arabian Gulf being the most northerly extent, where one species - Avicennia marina - is dominant (Almardeai et al., 2017).

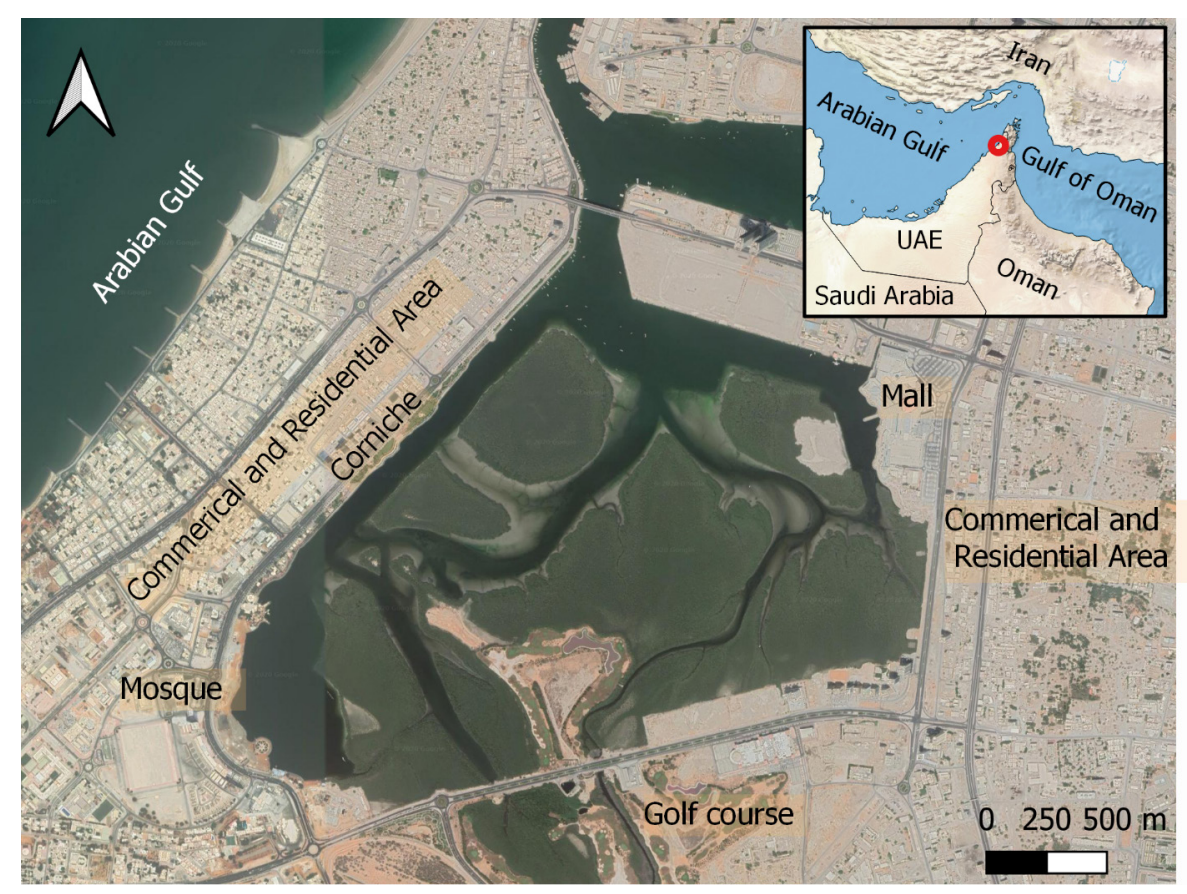

Figure 1. The geographical location of the mangrove wetland in Ras Al Khaimah, UAE 
Mangroves have evolved from terrestrial species to adapt to inundated, highly saline, soft and oxygen-poor soil (Kathiresan \& Bingham, 2001). Mangroves have adapted to this harsh environment through several mechanisms. Species - such as Avicennia marina - have roots (known as pneumatophore) that grow vertically upward with their tips extending above water during low tides. Oxygen enters through pores at the tip of pneumatophores during low tides, and is prevented from entering the pores by repellent material during high tides (Feller, 2018). Mangroves dependency on this cyclical tidal water level oscillation makes it vulnerable to rising seawater levels due to human-induced climate change. During the Holocene, mangroves adapted to climatic changes by moving inland during high seawater levels by building up peat. However, the current anthropogenic climatic changes are possibly happening too fast for the mangroves to adapt to them (Jones et al., 2019). It is also important to limit coastal development near mangroves to leave room for mangroves to move inland as seawater levels rise.

Another key adaption of mangrove is their handling of high salinity. Two main mechanisms can be found: one where salt is prevented from entering the cells and the other by forcing salt out of the cells, and through leave pores. Both mechanisms require energy. Consequently, mangroves thrives better in seawaters with lower salinities. In fact, the abundance of rainfall in Southeast Asia is the primary reason for the dense mangrove forests, where some trees can grow up to 30 meters (Feller, 2018). In contrast, the mangroves in the Arabian Gulf are diminutive due to the high salinity of the Arabian Gulf which exceeds 40,000 parts per million (Smith et al., 2007). Consequently, the authors believe that the mangroves in the Arabian Gulf are threatened by the projected decrease in rainfall due to climate change.

\subsection{Overview of environmental value survey approach}

The rise of environmental stewardship was paralleled with and probably driven by - public concern over the state of environment. As environmental problems and disasters proliferated with economic growth, people have become more concerned with the accelerated industrial and urban development, and are increasingly demanding the employment of drastic measures to safeguard the environment and public health. Given that these measures may require tradeoffs with socio-economic development, it becomes necessary to inform and involve the public in the development of sustainability initiatives. Involving the public in sustainable decision-making, requires understanding their environmental values, which describe how they perceive environmental issues and how it should be managed.

Extensive body of literature has been published on the value-attitude-behavior cognitive framework (see Muzikante \& Renge, 2011; Ajzen, 2012; Gatersleben et al., 2014; Sneed, 2014). In this framework, the construct of value orientation has been identified as the most critical factor in explaining people's attitude and behavior (Paudyal et al., 2015). Three categories of value orientations are generally identified (van Uhm, 2016). The biocentric value orientation characterizes people who place the ecosystem wellbeing and maintenance above human ones. At the other end of the spectrum, the anthropocentric value orientation describes individuals who believe human socio-economic development take precedence over those of the ecosystem (Jenkins, 2016). As the middle-ground category, the ecocentric value orientation represents those who believe that a compromise should be struck between human welfare and ecosystem sustainability.

Researchers use surveys to directly assess public environmental values. With advancements in statistical analysis and knowledge on people behavior and attitudes, it has become possible to deduce valuable insight about public environmental values that help guide policy makers in drafting effective environmental policies. An environmental value survey consists of developing a questionnaire that gauges how a person view an environmental issue in relation to demographics factors. Several environmental value surveys are reported in literature. For example, Onel and Mukherjee (2012) applied an environmental value survey to assess the association of environmental behavior to several socio-economic and demographic factors, and attitude towards the environment. van Riper and Kyle (2014) used an environmental value study to get an insight on how people behave in national parks and why. Blye (2016) conducted an environmental value survey of park visitors in Canada to assess their knowledge of Leave- No-Trace (LNT) park waste-control program and global environmental views.

In the current study we deigned our questions to examine the associations of selected soci-economic and demographic factors to environmental values regarding the RAK mangrove wetland.

\section{Materials and methods}

The study was conducted using a public face-to-face interview-based survey composed of 22 questions that were designed to capture five socio-demographic factors in addition to the respondent's familiarity with the RAK mangrove ecosystem, and knowledge of the principle of sustainability. One of the questions was composed to elicit the person's environmental value orientation with respect to the RAK mangrove wetland.

Research assistants conducted the survey at different locations within Ras Al Khaimah including the AURAK campus, shopping areas, commercial districts and a popular corniche area that borders the RAK mangrove wetland. A total of 427 responses were collected. The responses were screened for inconsistencies and compiled using IBM SPSS. Data was analyzed using cross-tab analysis, where $\mathrm{p}$-values of $\chi^{2}$ (chi-squared) test are calculated. A low pvalue indicates that differences among given categories of respondents are unlikely due to chance, and consequently indicate that differences are significant. 


\subsection{Hypotheses}

Several hypotheses were postulated based on the findings from a review of literature on environmental values and attitudes. In the following sections, seven hypotheses are presented. They relate to gender, age, education, income, length of residency in RAK, knowledge of the RAK mangrove wetland and knowledge of the concept of sustainability.

\subsection{Background and premises}

\subsubsection{Gender}

Research on environmental behavior has shown that women tend to exhibit a more positive environmental attitude than men do (Xiao \& McCright, 2013; Goldsmith et al., 2013; Dietz et al., 2002). Xiao and McCright (2012) attributed this difference to the women's higher perception of risk. Brough et al. (2016) claim that femininity plays a major role in this difference, indicating that men tend to avoid positive environmental behavior to avoid being depicted as feminine. In contrast to these studies, Shen and Saijo (2008) pointed to a stronger pro-environmental concern among men than women in the population of Shanghai, China. We investigated the role of gender in shaping the environmental value of RAK residents towards mangroves.

\subsubsection{Age}

In a study of environmental concern tendency among the population of Shanghai, China, Shen and Saijo (2008) have found that older generations are more environmentally inclined than younger generations. This finding is supported by Grendstad and Wollebaek (1998). In contrast, an earlier study in the USA (Jones \& Dunlap, 1992) indicated that younger adults are more concerned with the environment than older adults. Despite their contrary findings, these studies show that age has a role in shaping an individual's environmental values. Consequently, we expect that age is a factor in determining the RAK residents' environmental value orientation with respect to the mangroves.

\subsubsection{Education}

Review of previous studies on the association between education level and environmental value orientation show varying results. On one hand, Vaske et al. (2001) concluded that highly educated individuals are more likely to have a biocentric orientation. In contrast, Grendstad and Wollebaek (1998) indicated that education is negatively associated with positive environmental orientation. This is also supported by Holloway (2009), who found that the vast majority (85\%) of respondents in her study with biocentric orientation have less than high school education, and the majority (56\%) of respondents with anthropocentric orientation had a graduate or professional degree. Notwithstanding these conflicting findings, it is obvious from these studies that environmental value orientation is associated with education.

\subsubsection{Income}

Gamborg and Jensen (2015) analysis of Danish public's wildlife value orientation did not support their hypothesis that higher-income individuals are more inclined to be biocentric than their lower-income counterparts are. Similarly, Kölmek (2011) found that those with higher income show less environmental concern. Teel and Manfredo (2010) indicated that wild life value orientations are weakly linked to income.

\subsubsection{Residency in RAK}

Research points to differences between new comers and long-term residents in how each group value natural ecosystems. Vaske et al. (2001) indicated that new comers to rural areas are more inclined to support preservation of national forests (biocentric orientation), while long-term residents were less receptive to national forest preservation measures and lean more towards integrated socioeconomic management of natural resources (ecocentric orientation). In contrast, Manfredo and Zinn (1996) found insignificant difference between the wildlife value orientations of short and long-term residents. We speculate that length of residency influences an individual's environmental value orientation.

\subsubsection{Knowledge of the RAK Mangrove wetland}

Kennedy et al. (2009) emphasized the role of knowledge of environmental issues in motivating people to behave environmentally friendly. Otto and Kaiser (2014) highlighted the role of environmental knowledge in shaping people's interest in protecting the environment. Liobikiene and Poškus (2019) indicated that behavior with respect to environmental issues is highly influenced by knowledge of these issues. Consequently, an individual's knowledge of the RAK mangrove wetland is expected to be associated with his/her environmental value orientation with respect to the RAK mangroves.

\subsubsection{Awareness of sustainability}

Ajzen et al. (2011) showed that although knowledge is not a predictor of behavior, it does influence intention. This is also supported by Hereen et al. (2016) who found, based on a study of over 500 students in a major university in the USA, that weak correlation between sustainability knowledge and behavior is largely explained by attitudes and norms. In this study we intent to examine the relationship between sustainability knowledge and environmental value orientation.

Accordingly, we postulated the following hypotheses:

Hypotheses: Environmental value orientation regarding the RAK Mangrove wetland is associated with:

H1: Gender

H2: Age

H3: Education

H4: Income

H5: Residency in RAK

H6: Knowledge of the RAK Mangrove wetland

H7: Awareness of sustainability 


\section{Results}

A total of 427 responses were collected. The responses were screened for inconsistencies and compiled using IBM SPSS. Summary of survey results are shown in Table 1. The results show that the majority of respondents have a biocentric value orientation (59.4\%) with very few who hold an anthropocentric value orientation (6.6\%). The remaining respondents (34\%) are reported to have an ecocentric value orientation.

Table 1. Summary of survey results. Number in brackets show the count of respondents

\begin{tabular}{|c|c|c|c|c|}
\hline \multicolumn{5}{|c|}{ Environmental value orientations } \\
\hline Factor & $\begin{array}{c}\text { Bio- } \\
\text { centric }\end{array}$ & $\begin{array}{c}\text { Eco- } \\
\text { centric }\end{array}$ & $\begin{array}{l}\text { Anthro- } \\
\text { pocentric }\end{array}$ & $\begin{array}{l}\text { Across all } \\
\text { categories }\end{array}$ \\
\hline \multicolumn{5}{|l|}{ Gender } \\
\hline Female & $\begin{array}{c}59.6 \% \\
(90)\end{array}$ & $\begin{array}{c}35.8 \% \\
(54)\end{array}$ & $\begin{array}{l}4.6 \% \\
(07)\end{array}$ & $\begin{array}{c}35.4 \% \\
(151)\end{array}$ \\
\hline Male & $\begin{array}{l}59.3 \% \\
(163)\end{array}$ & $\begin{array}{c}33.1 \% \\
(91)\end{array}$ & $\begin{array}{c}7.6 \% \\
(21)\end{array}$ & $\begin{array}{c}64.6 \% \\
(275)\end{array}$ \\
\hline All & $\begin{array}{c}59.4 \% \\
(253)\end{array}$ & $\begin{array}{c}34.0 \% \\
(145)\end{array}$ & $\begin{array}{c}6.6 \% \\
(28)\end{array}$ & $\begin{array}{c}100.0 \% \\
(426)\end{array}$ \\
\hline \multicolumn{5}{|l|}{ Age } \\
\hline$<25 \mathrm{yrs}$ & $\begin{array}{c}54.1 \% \\
(66)\end{array}$ & $\begin{array}{c}38.5 \% \\
(47)\end{array}$ & $\begin{array}{l}7.4 \% \\
(09)\end{array}$ & $\begin{array}{c}28.6 \% \\
(122)\end{array}$ \\
\hline 25 to $34 \mathrm{yrs}$ & $\begin{array}{c}53.3 \% \\
(90)\end{array}$ & $\begin{array}{c}40.2 \% \\
(68)\end{array}$ & $\begin{array}{l}6.5 \% \\
(11)\end{array}$ & $\begin{array}{c}39.7 \% \\
(169)\end{array}$ \\
\hline 35 to $44 \mathrm{yrs}$ & $\begin{array}{c}72.8 \% \\
(67)\end{array}$ & $\begin{array}{c}22.8 \% \\
(21)\end{array}$ & $\begin{array}{l}4.3 \% \\
(04)\end{array}$ & $\begin{array}{c}21.6 \% \\
(92)\end{array}$ \\
\hline$>44 \mathrm{yrs}$ & $\begin{array}{c}69.8 \% \\
(30)\end{array}$ & $\begin{array}{c}20.9 \% \\
(09)\end{array}$ & $\begin{array}{c}9.3 \% \\
(04)\end{array}$ & $\begin{array}{c}10.1 \% \\
(43)\end{array}$ \\
\hline All & $\begin{array}{c}59.4 \% \\
(253)\end{array}$ & $\begin{array}{c}34.0 \% \\
(145)\end{array}$ & $\begin{array}{l}6.6 \% \\
(28)\end{array}$ & $\begin{array}{c}100.0 \% \\
(426)\end{array}$ \\
\hline \multicolumn{5}{|l|}{ Education } \\
\hline$<$ H. School & $\begin{array}{c}61.9 \% \\
(13)\end{array}$ & $\begin{array}{c}33.3 \% \\
(07)\end{array}$ & $\begin{array}{l}4.8 \% \\
(01)\end{array}$ & $4.9 \%(21)$ \\
\hline H. School & $\begin{array}{c}55.1 \% \\
(43)\end{array}$ & $\begin{array}{c}39.7 \% \\
(31)\end{array}$ & $\begin{array}{l}5.1 \% \\
(04)\end{array}$ & $\begin{array}{c}18.3 \% \\
(78)\end{array}$ \\
\hline A. Degree & $\begin{array}{c}58.1 \% \\
(54)\end{array}$ & $\begin{array}{c}28.0 \% \\
(26)\end{array}$ & $\begin{array}{c}14.0 \% \\
(13)\end{array}$ & $\begin{array}{c}21.8 \% \\
(93)\end{array}$ \\
\hline B. Degree & $\begin{array}{c}59.6 \% \\
(115)\end{array}$ & $\begin{array}{c}36.3 \% \\
(70)\end{array}$ & $\begin{array}{l}4.1 \% \\
(08)\end{array}$ & $\begin{array}{l}45.3 \% \\
(193)\end{array}$ \\
\hline G. Degree & $\begin{array}{c}68.3 \% \\
(28)\end{array}$ & $\begin{array}{c}26.8 \% \\
(11)\end{array}$ & $\begin{array}{l}4.9 \% \\
(02)\end{array}$ & $9.6 \%(41)$ \\
\hline All & $\begin{array}{c}59.4 \% \\
(253)\end{array}$ & $\begin{array}{c}34.0 \% \\
(145)\end{array}$ & $\begin{array}{l}6.6 \% \\
(28)\end{array}$ & $\begin{array}{c}100.0 \% \\
(426)\end{array}$ \\
\hline \multicolumn{5}{|l|}{ Income } \\
\hline$<5 \mathrm{k}$ & $\begin{array}{c}56.4 \% \\
(106)\end{array}$ & $\begin{array}{c}36.2 \% \\
(68)\end{array}$ & $\begin{array}{c}7.4 \% \\
(14)\end{array}$ & $\begin{array}{l}44.1 \% \\
(188)\end{array}$ \\
\hline $5 \mathrm{k}-10 \mathrm{k}$ & $\begin{array}{c}59.2 \% \\
(29)\end{array}$ & $\begin{array}{c}36.7 \% \\
(18)\end{array}$ & $\begin{array}{l}4.1 \% \\
(02)\end{array}$ & $\begin{array}{c}11.5 \% \\
(49)\end{array}$ \\
\hline $10 \mathrm{k}-20 \mathrm{k}$ & $\begin{array}{c}59.4 \% \\
(38)\end{array}$ & $\begin{array}{c}34.4 \% \\
(22)\end{array}$ & $\begin{array}{l}6.3 \% \\
(04)\end{array}$ & $\begin{array}{c}15.0 \% \\
(64)\end{array}$ \\
\hline$>20 \mathrm{k}$ & $\begin{array}{c}69.6 \% \\
(32)\end{array}$ & $\begin{array}{c}19.6 \% \\
(09)\end{array}$ & $\begin{array}{c}10.9 \% \\
(05)\end{array}$ & $\begin{array}{c}10.8 \% \\
(46)\end{array}$ \\
\hline
\end{tabular}

End of Table 1

\begin{tabular}{|c|c|c|c|c|}
\hline \multicolumn{5}{|c|}{ Environmental value orientations } \\
\hline Factor & $\begin{array}{c}\text { Bio- } \\
\text { centric }\end{array}$ & $\begin{array}{c}\text { Eco- } \\
\text { centric }\end{array}$ & $\begin{array}{c}\text { Anthro- } \\
\text { pocentric }\end{array}$ & $\begin{array}{c}\text { Across all } \\
\text { categories }\end{array}$ \\
\hline Unknown & $\begin{array}{c}60.8 \% \\
(48)\end{array}$ & $\begin{array}{c}35.4 \% \\
(28)\end{array}$ & $\begin{array}{c}3.8 \% \\
(03)\end{array}$ & $\begin{array}{c}18.5 \% \\
(79)\end{array}$ \\
\hline All & $\begin{array}{c}59.4 \% \\
(253)\end{array}$ & $\begin{array}{c}34.0 \% \\
(145)\end{array}$ & $\begin{array}{c}6.6 \% \\
(28)\end{array}$ & $\begin{array}{c}100.0 \% \\
(426)\end{array}$ \\
\hline
\end{tabular}

Residency in RAK

\begin{tabular}{|r|c|c|c|c|}
\hline$<1$ yr & $\begin{array}{c}59.1 \% \\
(52)\end{array}$ & $\begin{array}{c}35.2 \% \\
(31)\end{array}$ & $\begin{array}{c}5.7 \% \\
(05)\end{array}$ & $\begin{array}{c}20.7 \% \\
(88)\end{array}$ \\
\hline $2-4$ yrs & $\begin{array}{c}46.7 \% \\
(50)\end{array}$ & $\begin{array}{c}46.7 \% \\
(50)\end{array}$ & $\begin{array}{c}6.5 \% \\
(07)\end{array}$ & $\begin{array}{c}25.1 \% \\
(107)\end{array}$ \\
\hline $5-9$ yrs & $\begin{array}{c}47.8 \% \\
(22)\end{array}$ & $\begin{array}{c}43.5 \% \\
(20)\end{array}$ & $\begin{array}{c}8.7 \% \\
(04)\end{array}$ & $\begin{array}{c}10.8 \% \\
(46)\end{array}$ \\
\hline \multirow{2}{*}{$>10$ yrs } & $\begin{array}{c}69.7 \% \\
(129)\end{array}$ & $\begin{array}{c}23.8 \% \\
(44)\end{array}$ & $\begin{array}{c}6.5 \% \\
(12)\end{array}$ & $\begin{array}{c}43.4 \% \\
(185)\end{array}$ \\
\hline \multirow{2}{*}{ All } & $59.4 \%$ & $34.0 \%$ & $6.6 \%$ & $100.0 \%$ \\
& $(253)$ & $(145)$ & $(28)$ & $(426)$ \\
\hline
\end{tabular}

\begin{tabular}{|r|c|c|c|c|}
\hline \multicolumn{5}{|c|}{ Knowledge of mangrove } \\
\hline Non & $\begin{array}{c}54.0 \% \\
(94)\end{array}$ & $\begin{array}{c}35.1 \% \\
(61)\end{array}$ & $\begin{array}{c}10.9 \% \\
(19)\end{array}$ & $\begin{array}{c}40.8 \% \\
(174)\end{array}$ \\
\hline Little & $\begin{array}{c}60.7 \% \\
(65)\end{array}$ & $\begin{array}{c}35.5 \% \\
(38)\end{array}$ & $\begin{array}{c}3.7 \% \\
(04)\end{array}$ & $\begin{array}{c}25.1 \% \\
(107)\end{array}$ \\
\hline Moderate & $\begin{array}{c}63.1 \% \\
(53)\end{array}$ & $\begin{array}{c}35.7 \% \\
(30)\end{array}$ & $\begin{array}{c}1.2 \% \\
(01)\end{array}$ & $\begin{array}{c}19.7 \% \\
(84)\end{array}$ \\
\hline Very good & $\begin{array}{c}73.7 \% \\
(28)\end{array}$ & $\begin{array}{c}23.7 \% \\
(09)\end{array}$ & $\begin{array}{c}2.6 \% \\
(01)\end{array}$ & $8.9 \%(38)$ \\
\hline All & $\begin{array}{c}59.4 \% \\
(253)\end{array}$ & $\begin{array}{c}34.0 \% \\
(145)\end{array}$ & $\begin{array}{c}6.6 \% \\
(28)\end{array}$ & $\begin{array}{c}100.0 \% \\
(426)\end{array}$ \\
\hline
\end{tabular}

Sustainability awareness

\begin{tabular}{|c|c|c|c|c|}
\hline Non & $\begin{array}{c}49.7 \% \\
(77)\end{array}$ & $\begin{array}{c}38.7 \% \\
(60)\end{array}$ & $\begin{array}{c}11.6 \% \\
(18)\end{array}$ & $\begin{array}{c}36.6 \% \\
(155)\end{array}$ \\
\hline Little & $\begin{array}{c}73.2 \% \\
(60)\end{array}$ & $\begin{array}{c}24.4 \% \\
(20)\end{array}$ & $\begin{array}{c}2.4 \% \\
(02)\end{array}$ & $\begin{array}{c}19.4 \% \\
(82)\end{array}$ \\
\hline Moderate & $\begin{array}{c}58.6 \% \\
(65)\end{array}$ & $\begin{array}{c}37.8 \% \\
(42)\end{array}$ & $\begin{array}{c}3.6 \% \\
(04)\end{array}$ & $\begin{array}{c}26.2 \% \\
(111)\end{array}$ \\
\hline Very good & $\begin{array}{c}57.9 \% \\
(22)\end{array}$ & $\begin{array}{c}39.5 \% \\
(15)\end{array}$ & $\begin{array}{c}2.6 \% \\
(01)\end{array}$ & $9.0 \%(38)$ \\
\hline Excellent & $\begin{array}{c}70.3 \% \\
(26)\end{array}$ & $\begin{array}{c}21.6 \% \\
(08)\end{array}$ & $\begin{array}{c}8.1 \% \\
(03)\end{array}$ & $8.7 \%(37)$ \\
\hline All & $\begin{array}{c}59.1 \% \\
(250)\end{array}$ & $\begin{array}{c}34.3 \% \\
(145)\end{array}$ & $\begin{array}{l}6.6 \% \\
(28)\end{array}$ & $\begin{array}{c}100.0 \% \\
(423)\end{array}$ \\
\hline
\end{tabular}

Data were analyzed using cross-tab analysis. Results from the analysis are summarized in Table 2 and presented in the following sections.

\subsection{Gender}

We applied interviews to 151 females and 275 males. Figure 2 shows the distribution of environmental value orientation related to gender (the RAK Mangrove wetland ecosystem value orientation vs. gender). The p-value of 
Table 2. P-values of $\chi^{2}$ for the associations of various factors with environmental value orientations

\begin{tabular}{|c|c|c|c|c|c|c|}
\hline Gender & Age & Education & Income & $\begin{array}{c}\text { Residency in } \\
\text { RAK }\end{array}$ & $\begin{array}{c}\text { Knowledge of } \\
\text { mangrove }\end{array}$ & $\begin{array}{c}\text { Sustainability } \\
\text { awareness }\end{array}$ \\
\hline 0.463 & 0.023 & 0.095 & 0.509 & 0.003 & 0.039 & 0.005 \\
\hline
\end{tabular}

$\chi^{2}$ from cross-tab analysis is 0.463 . This value suggests no appreciable differences between the RAK Mangrove value orientations of females and males. Consequently, we reject hypothesis $\mathrm{H} 1$.

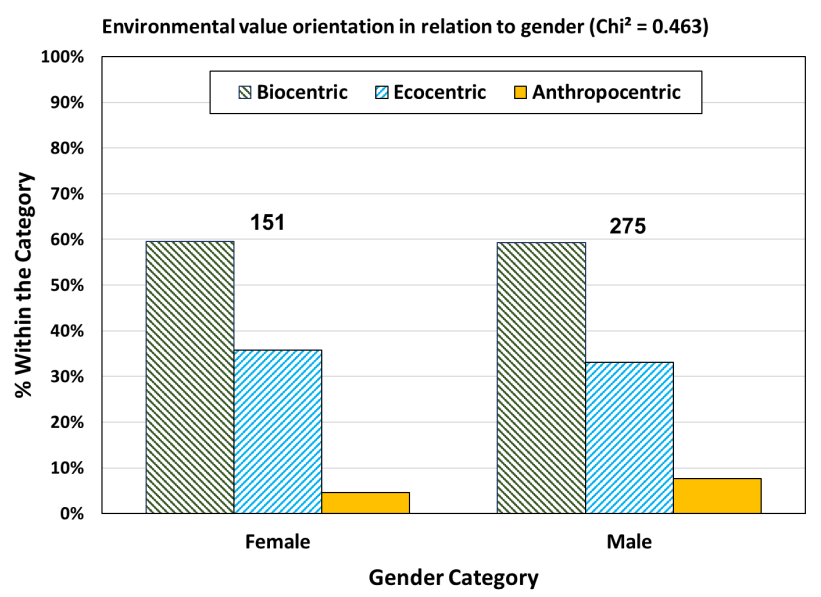

Figure 2. Distribution of environmental value orientation in relation to gender

\subsection{Age}

The results for age are shown in Figure 3. The p-value of $\chi^{2}$ for age in relation to RAK Mangrove value orientation is 0.023 , which indicates that there is a borderline differentiation in RAK Mangrove value orientation with respect to age, which indicates that hypothesis $\mathrm{H} 2$ is not strongly supported by data. Figure 3 shows that respondents 35 years old or above are overwhelmingly biocentric compared to younger individuals.

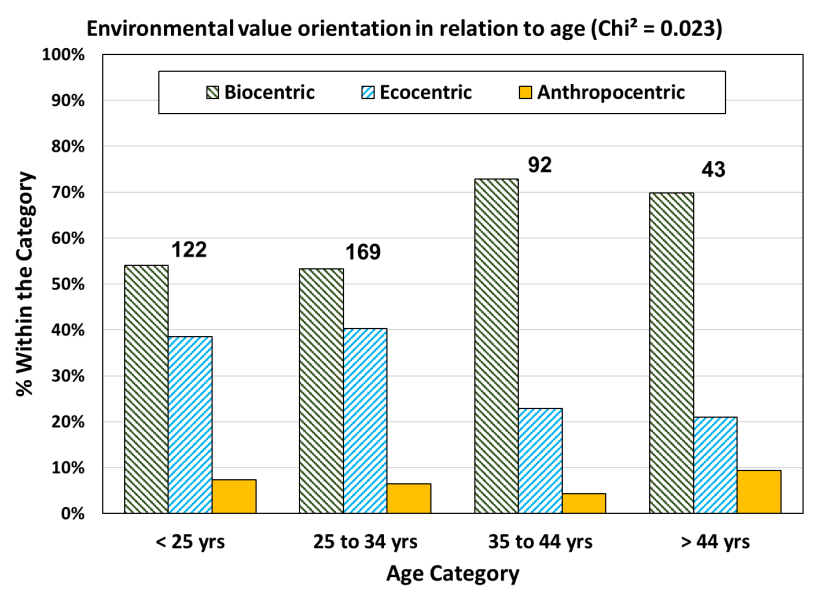

Figure 3. Distribution of environmental value orientation in relation to age

\subsection{Education}

The results for education are shown in Figure 4. The pvalue of $\chi^{2}$ for education in relation to RAK ecosystem value orientation is 0.095 , which indicates a weak differentiation in value orientation with respect to education, and consequently leads us to reject hypothesis H3. There is however a larger number of those with anthropocentric value orientation among those with associate degree, and a larger number of biocentric respondents among those with graduate degrees.

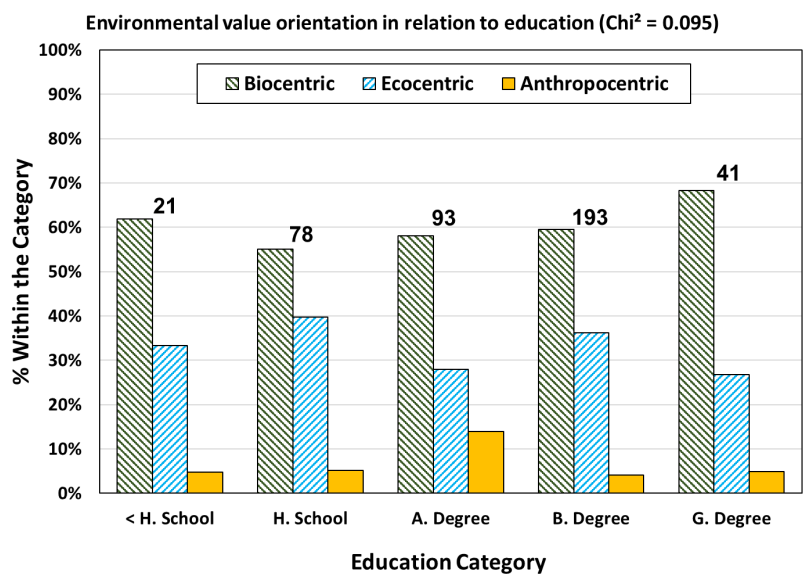

Figure 4. Distribution of environmental value orientation in relation to education

\subsection{Income}

The results for cross-tab analysis of income vs. RAK Mangrove value orientation is presented in Figure 5. The analysis yields a p-value of $\chi^{2}$ equal to 0.509 , which indicates

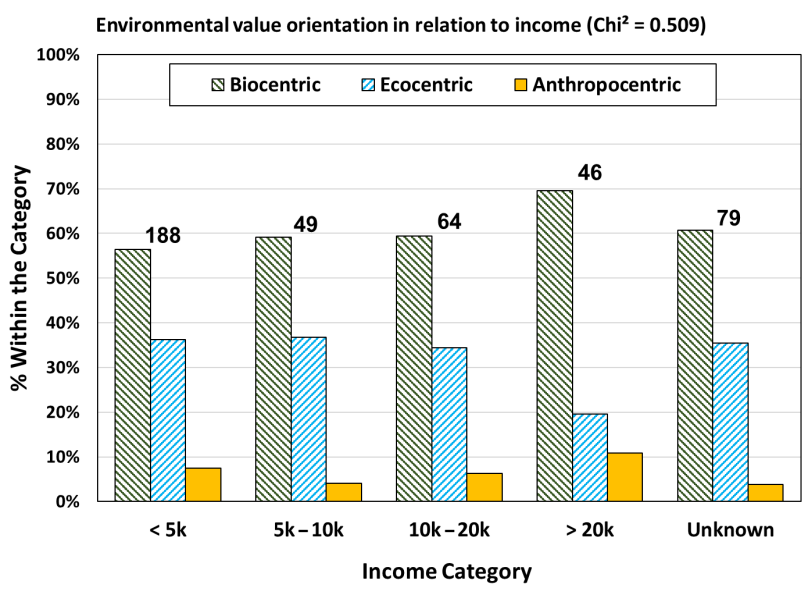

Figure 5. Distribution of environmental value orientation in relation to income 
that value orientations are largely independent of income level, which leads to rejecting hypothesis H4. It should be noted that a significant number of respondents chose not to reveal their income category.

\subsection{Residency in RAK}

Cross-tab analysis of the length of residency in RAK vs. RAK Mangrove value orientation are presented in Figure 6. With a p-value of $\chi^{2}$ equal to 0.003 , the results indicate a significant association of value orientation with how long the person has been living in RAK. Consequently, hypothesis $\mathrm{H} 5$ is accepted. Figure 6 shows that those who have been living in RAK for over 10 years are more inclined to be biocentric. Interestingly, those who have lived less than one year come second in the biocentric value orientation category. Both middle classes have a lower percentage of those with biocentric value orientation. However, they both have a share of ecocentrism higher than the low residency and high residency categories.

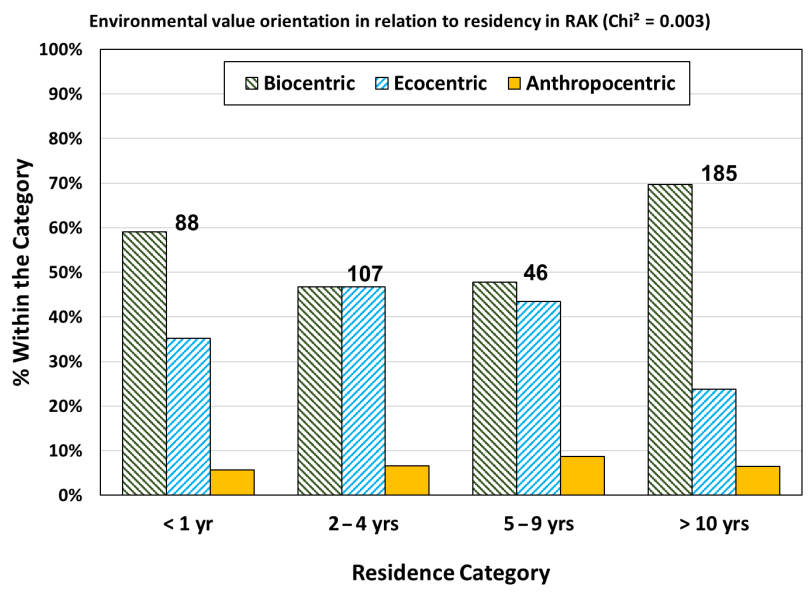

Figure 6. Distribution of environmental value orientation in relation to residency in RAK

\subsection{Knowledge of the RAK Mangrove Wetland Ecosystem}

Respondents were asked to rank their knowledge of the RAK Mangrove wetland ecosystem from knowing nothing about it to having a lot of knowledge about it. The crosstab analysis of these responses are presented in Figure 7. A $\mathrm{p}$-value of $\chi^{2}$ equal to 0.039 points to a borderline association between knowledge of the RAK Mangrove wetland and its associated value orientations, which leads to not rejecting hypothesis H6. Those with good knowledge of the RAK mangrove wetland tend to be biocentric more often than other categories, including those who described themselves to know a lot about the RAK Mangrove wetland. Interestingly, this latter group has the highest anthropocentric respondents among all knowledge categories. It should be noted that the measure of knowledge is based on the individuals own assessment, which may not be accurate.

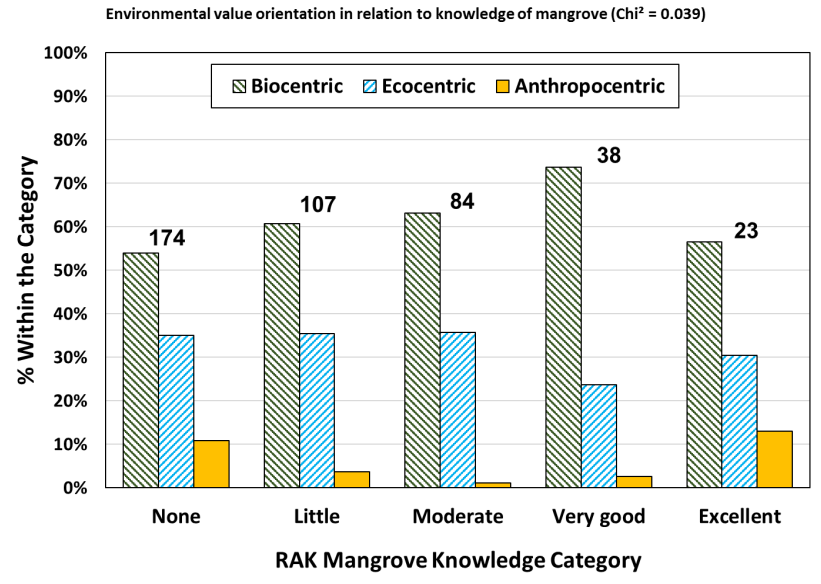

Figure 7. Distribution of environmental value orientation in relation to knowledge of the RAK mangrove wetland

\subsection{Awareness of sustainability}

Figure 8 shows cross-tab analysis results of awareness of sustainability vs. RAK Mangrove value orientation. The $\mathrm{p}$-value of $\chi^{2}$ equal to 0.005 indicates that environmental value orientation is significantly linked to the level of awareness of sustainability, which leads us to accept hypothesis H5. However, there is no consistent relationship between the two variables. Those with excellent level of sustainability awareness and those with little awareness have a higher percentage of individuals with biocentric orientation and lower percentage of individuals with ecocentric views, respectively, than those with moderate and high level of sustainability awareness.

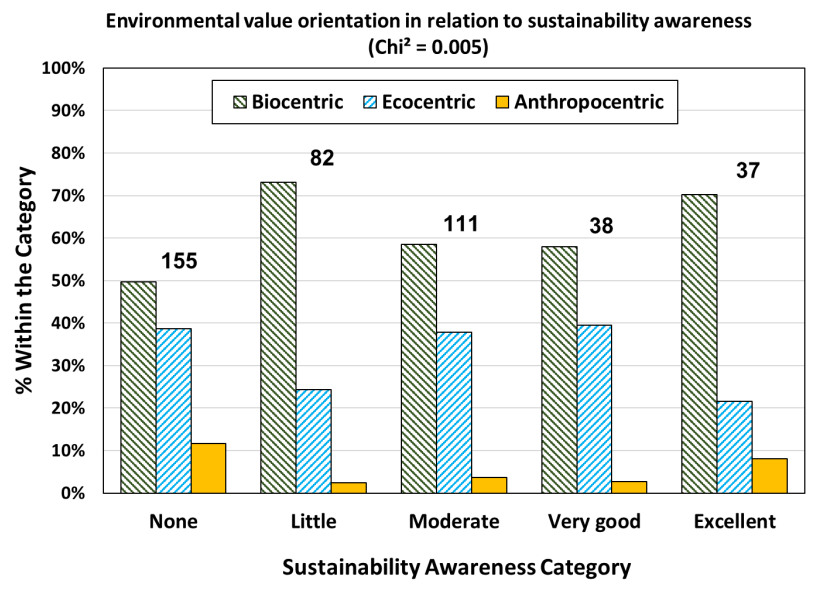

Figure 8. Distribution of environmental value orientation in relation to sustainability awareness

\section{Discussion}

The results show that several factors are associated - with varying degrees - with the person's environmental value orientation with respect to the RAK mangrove wetlands. Residency stands out as the most associated factor with value orientations. Long-term residents of RAK, and to a lesser extent, visitors to RAK are more likely to be in 
favor of strong protection of the RAK mangrove wetlands (Figure 6). Visitors are likely to be impressed by the urban setting of the mangrove wetlands, which is unique in the UAE and regionally. Long-term residents appear to be more concerned with protecting RAK's natural assets and would therefore adopt a stronger biocentric orientation.

There is a shift from biocentrism to ecocentrism among the two other groups who lived 2 to 4 years and 5 to 9 years, i.e. these two groups are leaning more towards allowing some development in conjunction with protection of the mangrove (Figure 6). There is no clear explanation of this observation. It is interesting to note however that these two groups are most likely expatriates who arrived to Ras $\mathrm{Al}$ Khaimah from other emirates or from abroad.

Level of sustainability awareness is the second most significant factor in differentiating environmental value orientations. This does not agree well with findings from literature review, which indicate a weak link between the two. The results from this study show an interesting observation: individuals with low awareness of sustainability are as predominately biocentric as individuals with excellent awareness of sustainability. In contrast, a shift towards ecocentrism occurs in groups with moderate and high level of sustainability awareness (Figure 8 ). It is not clear what causes this polarization in value orientations. It could be related to how people perceive or interpret sustainability. The concept of sustainability is predicated on establishing a balance among socio-economic development and environmental protection. As such, it is more represented by the ecocentric value orientation, which advocates sustainable development.

Despite the weak support for hypothesis $\mathrm{H} 2$ in relation to age, older individuals are more likely to be more biocentric in their view of RAK mangroves than younger individuals are (Figure 3). This is in line with most findings in literature. It should be noted however that despite the lower prevalence of biocentrisim among younger individuals, they are more ecocentric indicating their preference for integrating economic development with environmental protection.

Knowledge of the mangrove wetland seems to play a more ambiguous role in shaping mangrove value orientations. Like those with no knowledge of mangroves from RAK, people who reported excellent understanding (knowledge) of mangroves are less likely to be biocentric and more likely to be anthropocentric than those who said they have little or only limited perception (knowledge) of mangroves (Figure 7). Notwithstanding that anthropocentric individuals are a minority among all groups, their higher percentage among those who claim to have excellent knowledge of the mangrove, may point to a misunderstanding of the mangrove and the suspicion some respondents have that mangrove are causing bad odor in the area.

Mangrove value orientation are weakly associated with level of education. There is however a noticeably higher percentage of anthropocentric individuals among those with associate degree in comparison to other education categories.
Results show that mangrove value orientation is largely independent of gender and income. This contrasts with some studies in the literature.

\section{Conclusions}

This study was set out to investigate the association between the environmental value orientation of Ras $\mathrm{Al}$ Khaimah residents with respect to RAK mangroves and a set of socio-economic, demographic and environmental knowledge factors. The results shows that residency in Ras Al Khaimah is the most important factor in differentiating RAK mangrove value orientations. Long-term residents and new residents share similar characteristics: both groups lean toward offering the RAK mangroves more protection against socio-economic development in comparison to medium term residents.

Environmental value orientation is also associated with the level of sustainability awareness. As expected, those with consolidated sustainability awareness are more biocentric than those with good level of sustainability awareness. Surprisingly, however, individuals who characterized themselves as ignorant of sustainability issues are as nearly biocentric as those with excellent sustainability awareness.

Individual's knowledge of the RAK mangroves appeared to be weakly associated with the individual's environmental value orientation. It is interesting to note that a relatively significant percentage of those who have indicated having an excellent knowledge of the RAK mangrove are anthropocentric favoring socio-economic development over protection of the mangrove.

RAK mangrove value orientations are weakly associated with education, and virtually independent of gender and income.

More detailed research is required investigate some of these unexpected results, particularly in relation to residency in Ras $\mathrm{Al}$ Khaimah and level of sustainability awareness.

The overwhelmingly biocentric view among respondents indicates strong public support to protect the mangrove wetland even at the expense of economic development. It is consequently important to develop policies and regulations to safeguard this key ecosystem for current and future generations.

\section{Acknowledgements}

The authors would like to acknowledge the generous support of the Sheikh Saud bin Saqr Al Qasimi Foundation for Policy Research in funding this research.

\section{References}

Ajzen, I. (2012). Values, attitudes, and behavior. In S. Salzborn, E. Davidov, \& J. Reinecke (Eds.), Methods, theories, and empirical applications in the social sciences (pp. 33-38). VS Verlag für Sozialwissenschaften.

https://doi.org/10.1007/978-3-531-18898-0_5 
Ajzen, I., Joyce, N., Sheikh, S., \& Cote, N. G. (2011). Knowledge and the prediction of behavior: The role of information accuracy in the theory of planned behavior. Basic and Applied Social Psychology, 33(2), 101-117. https://doi.org/10.1080/01973533.2011.568834

Almardeai, S., Oyanedel, J.-R. B., Haris, S., \& Schmidt, J. E. (2017). Avicennia marina biomass characterization towards bioproducts. Emirates Journal of Food and Agriculture, 29(9), 710-715. https://doi.org/10.9755/ejfa.2017.v29.i9.109

Atchison, J. (2019). Green and blue infrastructure in Darwin; carbon economies and the social and cultural dimensions of valuing urban mangroves in Australia. Urban Science, 3(3), 86. https://doi.org/10.3390/urbansci3030086

Beech, M., \& Hogarth, P. (2002). An archaeological perspective on the development and exploitation of mangroves in the United Arab Emirates. In Research and management options for mangrove and salt marsh ecosystems (pp. 196-198). ERWDA.

Blye, C. J. (2016). What are people doing in our parks? Understanding, comparing, and predicting the low-impact camping practices of Canadian Provincial Park over-night visitors [Master's thesis]. University of Alberta, Canada. https://era.library. ualberta.ca/items/c7645bdf-c81f-4f76-8173-3c2074ca5e81/ view/e49ff7d5-9793-4c84-8321-9da010db97fd/blye_clarajane_e_201609_MA.pdf

Brough, A. R., Wilkie, J. E. B., Ma, J., Isaac, M. S., \& Gal, D. (2016). Is eco-friendly unmanly? The green-feminine stereotype and its effect on sustainable consumption. Journal of Consumer Research, 43(4), 567-582. https://doi.org/10.1093/jcr/ucw044

Dietz, T., Kalof, L., \& Stern, P. C. (2002). Gender, values, and environmentalism. Social Science Quarterly, 83(1), 353-364. https://doi.org/10.1111/1540-6237.00088

Feller, C. (2018). Mangroves. Smithsonian. https://ocean.si.edu/ ocean-life/plants-algae/mangroves

Gamborg, C., \& Jensen, F. S. (2015). Wildlife Value Orientations: A quantitative study of the general public in Denmark. $\mathrm{Hu}$ man Dimensions of Wildlife, 21(1), 34-46.

https://doi.org/10.1080/10871209.2015.1098753

Gatersleben, B., Murtagh, N., \& Abrahamse, W. (2014). Values, identity and pro-environmental behavior. Contemporary Social Science, 9(4), 374-392.

https://doi.org/10.1080/21582041.2012.682086

Goldsmith, R., Fyegina, I., \& Jost, J. T. (2013). The gender gap in environmental attitudes: A system justification perspective. In M. Alston \& K. Whittenbury (Eds.), Research, action and policy: Addressing the gendered impacts of climate change (pp. 159-174). Springer.

https://doi.org/10.1007/978-94-007-5518-5_12

Grendstad, G., \& Wollebaek, D. (1998). Greener still?: An empirical examination of Eckersley's ecocentric approach. Environment and Behavior, 30(5), 653-675.

https://doi.org/10.1177/001391659803000504

Heeren, A. J., Singh, A. S., Zwickle, A., Koontz, T. M., Slagle, K. M., \& McCreery, A. C. (2016). Is sustainability knowledge half the battle? International Journal of Sustainability in Higher Education, 17(5), 613-632.

https://doi.org/10.1108/IJSHE-02-2015-0014

Holloway, M. V. (2009). Moderating effects of knowledge, gender, and education on the relationship between environmental value orientation and support for Louisiana coastal restoration [LSU Master's theses No 3403]. https://digitalcommons.lsu.edu/ gradschool_theses/3403
Hsieh, H.-L., Lin, H.-J., Shih, S.-S., \& Chen, C.-P. (2015). Ecosystem functions connecting contributions from ecosystem services to human wellbeing in a mangrove system in northern Taiwan. International Journal of Environmental Research and Public Health, 12(6), 6542-6560.

https://doi.org/10.3390/ijerph120606542

Jenkins, J. (2016). Contested terrain of extractive development in the American West: Using a regional political ecology framework to understand scale, biocentric conservation values, and anthropocentric resource utility. Journal of Political Ecology, 23, 182-196. https://doi.org/10.2458/v23i1.20189

Jones, M. C., Wingard, G. L., Stackhouse, B., Keller, K., Willard, D., Marot, M., Landacre, B., \& Bernhardt, C. E. (2019). Rapid inundation of southern Florida coastline despite low relative sea-level rise rates during the late-Holocene. Nature Communications, 10(1), 3231.

https://doi.org/10.1038/s41467-019-11138-4

Jones, R. E., \& Dunlap, R. E. (1992). The social bases of environmental concern: Have they changed over time? Rural Sociology, 57(1), 28-47.

https://doi.org/10.1111/j.1549-0831.1992.tb00455.x

Joshi, A. R., Dinerstein, E., Wikramanayake, E., Anderson, M. L., Olson, D., Jones, B. S., Seidensticker, J., Lumpkin, S., Hansen, M. C., Sizer, N. C., Davis, C. L., Palminteri, S., \& Hahn, N. R. (2016). Tracking changes and preventing loss in critical tiger habitat. Science Advances, 2(4), e1501675. https://doi.org/10.1126/sciadv.1501675

Kathiresan, K., \& Bingham, B. L. (2001). Biology of mangroves and mangrove Ecosystems. Advances in Marine Biology, 40, 81-251. https://doi.org/10.1016/S0065-2881(01)40003-4

Kennedy, E., Beckley, T., McFarlane, B., \& Nadeau, S. (2009). Why we don't "Walk the Talk": Understanding the environmental values/behaviour gap in Canada. Human Ecology Review, 16(2), 151-160. www.jstor.org/stable/24707539

Kölmek, E. F. (2011). Social determinants of environmental concern: The case of Cukurambar, Ankara [Master of Fine Arts, Dhsan Dogramaci Bdlkent University]. https://core.ac.uk/ download/pdf/52926170.pdf

Lazzarini, M., Marpu, P. R., \& Ghedira, H. (2012). Land cover and Land Surface Temperature interactions in desert areas: A case study of Abu Dhabi (UAE). IEEE International Geoscience and Remote Sensing Symposium (pp. 6325-6328). IEEE. https://doi.org/10.1109/IGARSS.2012.6352706

Liobikienè, G., \& Poškus, M. S. (2019). The importance of environmental knowledge for private and public sphere proenvironmental behavior: Modifying the Value-Belief-Norm theory. Sustainability, 11(12), 3324. https://doi.org/10.3390/su11123324

Manfredo, M. J., \& Zinn, H. C. (1996). Population change and its implications for wildlife management in the New West: A case study of Colorado. Human Dimensions of Wildlife, 1(3), 62-74. https://doi.org/10.1080/10871209609359070

Moriceau, J. (2014). The wolf threat in France from the middle ages to the twentieth century. https://hal.archives-ouvertes.fr/ hal-01011915

Muzikante, I., \& Renge, V. (2011). Attitude function as a moderator in values-attitudes-behavior relations. Procedia - Social and Behavioral Sciences, 30, 1003-1008.

https://doi.org/10.1016/j.sbspro.2011.10.195

Naser, H. A. (2014). Marine ecosystem diversity in the Arabian Gulf: Threats and conservation. In O. Grillo (Ed.), Biodiversity - The dynamic balance of the planet.

https://doi.org/10.5772/57425 
Nasution, A., Perwitasari-Farajallah, D., \& Utami-Atmoko, S. S. (2018). Declining orangutans population in the unprotected forest of Batang Toru. Tropical Life Sciences Research, 29(2), 77-87. https://doi.org/10.21315/tlsr2018.29.2.6

Onel, N., \& Mukherjee, A. (2012). Analysis of the predictors of environmentally sensitive behavior. International Journal of Data Analysis and Information Systems, 4(1), 55-67.

Otto, S., \& Kaiser, F. G. (2014). Ecological behavior across the lifespan: Why environmentalism increases as people grow older. Journal of Environmental Psychology, 40, 331-338. https://doi.org/10.1016/j.jenvp.2014.08.004

Paudyal, R., Poudyal, N. C., Bowker, J. M., Dorison, A. M., Zarnoch, S. J., \& Green, G. T. (2015). A value orientation approach to assess and compare climate change risk perception among trout anglers in Georgia, USA. Journal of Outdoor Recreation and Tourism, 11, 22-33. https://doi.org/10.1016/j.jort.2015.06.004

Shen, J., \& Saijo, T. (2008). Reexamining the relations between socio-demographic characteristics and individual environmental concern: Evidence from Shanghai data. Journal of Environmental Psychology, 28(1), 42-50. https://doi.org/10.1016/j.jenvp.2007.10.003

Smith, R., Purnama, A., \& Al-Barwani, H. H. (2007). Sensitivity of hypersaline Arabian Gulf to seawater desalination plants. Applied Mathematical Modelling, 31(10), 2347-2354. https://doi.org/10.1016/j.apm.2006.09.010

Sneed, C. T. (2014). Local food purchasing in the farmers' market channel: Value-attitude-behavior theory [PhD dissertation,
University of Tennessee, Knoxville]. https://trace.tennessee. edu/utk_graddiss/3168

Teel, T. L., \& Manfredo, M. J. (2010). Understanding the diversity of public interests in wildlife conservation. Conservation Biology, 24(1), 128-139. https://doi.org/10.1111/j.1523-1739.2009.01374.x

van Riper, C. J., \& Kyle, G. T. (2014). Understanding the internal processes of behavioral engagement in a national park: A latent variable path analysis of the value-belief-norm theory. Journal of Environmental Psychology, 38, 288-297. https://doi.org/10.1016/j.jenvp.2014.03.002

van Uhm, D. P. (2016). A green criminological perspective on environmental crime: The anthropocentric, ecocentric and biocentric impact of defaunation. Revue Internationale de Droit Pénal, 87(1), 323-340.

Vaske, J. J., Donnelly, M. P., Williams, D. R., \& Jonker, S. (2001). Demographic influences on environmental value orientations and normative beliefs about national forest management. Society \& Natural Resources, 14(9), 761-776. https://doi.org/10.1080/089419201753210585

Xiao, C., \& McCright, A. M. (2012). Explaining gender differences in concern about environmental problems in the United States. Society \& Natural Resources, 25(11), 1067-1084. https://doi.org/10.1080/08941920.2011.651191

Xiao, C., \& McCright, A. M. (2013). Gender differences in environmental concern. Environment and Behavior, 47(1), 17-37. https://doi.org/10.1177/0013916513491571 